\title{
Ultrastructure of sensilla on antennae and maxillary palps in three Mesembrinellidae species
}

Rebecca Leal Caetano ${ }^{1,2}$, César Carriço ${ }^{1,3^{*}}$, Doris Mendonça de Abreu Freitas ${ }^{2}$ and Zeneida Teixeira Pinto ${ }^{1}$

\begin{abstract}
Background: Having the right identification is essential in the field of entomology. The scanning electron microscopy allows rapid and accurate identification of different species of flies since a better visualization of the external morphology of immature and some adults is possible. The aim of this study is to describe some ultrastructures of three flies in the Mesembrinellidae family: Mesembrinella bellardiana; Mesembrinella bicolor and Mesembrinella semihyalina, all examined by scanning electron microscopy to help increase the anatomical database on flies and deal with phlylogenetic implications.

Results: The flies were examined under JEOL 6390LV scanning electron microscope (SEM). The microtrichia morphology of the antennae is similar to that of other and are present on all antennal surface with variable distribution. The chaetic sensilla were observed only in the scape (chaetic sensilla I) and pedicel segments (chaetic sensilla I-III). Three types of sensilla: trichoidea, basiconic and clavate were observed in the first flagellomere of $\mathrm{M}$. bellardiana; and two types of sensilla: trichoidea and basiconic were noticed in M. bicolor and M. semihyalina. Olfactory pits were observed in both gender of $\mathrm{M}$. bellardiana and female of $M$. bicolor. The maxillary palp of the Mesembrinella species in this study does not show sexual dimorphism.
\end{abstract}

Conclusion: This investigation provided new findings of some diagnostic structures of flies using SEM, since many of them could have not been observed just by the use of light microscopy.

Keywords: Arthropod, Brazil, Diptera, Ecology, Ultrastructural

\section{Background}

The Mesembrinellidae family is a small group of Diptera exclusively found in the Neotropical Region, and their species are distributed from southern Mexico to northern Argentina, with 36 described species distributed in nine genera $[6,10]$. Researches involving the family are restricted to the description and identification of species or the discussion of phylogenetic and systematic issues, with implications for taxonomic classification [23-25].

Species in this group are considered not adapted to the environment modified by man and have a very

\footnotetext{
*Correspondence: carrico82@gmail.com

'Instituto Oswaldo Cruz/Fundação Oswaldo Cruz (IOC/FIOCRUZ), Laboratório de Educação em Ambiente e Saúde, Avenida Brasil, 4365, Rio de Janeiro, RJ CEP 21040-900, Brazil

${ }^{3}$ Instituto Brasileiro de Medicina de Reabilitação-IBMR/Laureate International Universities, Av. das Américas, 2603, Barra da Tijuca, Rio de Janeiro CEP 22631-002, Brazil

Full list of author information is available at the end of the article
}

restricted habitat tolerance. They occur only in primary forest, being absent in almost secondary forest and degraded environments $[5,6,10,14]$. The family has potential to be a bioindicator for forest area, since they have high abundance and diversity in these environments [5]. The knowledge of the species of Diptera and the analysis of their occurrence in different environments is significant, for instance: specimens of Mesembrinella bellardiana Aldrich, 1922 and Mesembrinella peregrina Aldrich, 1922 are solely found in preserved sites of the Atlantic Forest. Gadelha et al. [5] corroborate this fact and suggest that the species of this genus can assist in monitoring the extension of anthropic impacts in the environment.

Morphological studies using Scanning Electron Microscopy (SEM) to clarify some structures on Hexapoda have been extensively conducted. For instance, such as: Ameismeier [1] described the chemosensitive basiconic 
on antennae of adults and embryonic stages of Locusta migratoria Linnaeus, 1758 (Orthoptera); Lopes et al. [9] found two types of basiconic sensilla on antennae of Phoracantha semipunctata (Fabricius, 1755) (Coleoptera); Sukontason et al. [18] studied the antennal sensilla of the families Calliphoridae, Sarcophagidae and Muscidae (Diptera), and they observed that the sensilla types were morphologically similar; Nascimento et al. [13] who described, the antennae sensillas of Melipona scutellaris Latreille, 1811 (Hymenoptera) collected from different altitudes, reveling the differences of trichoidea sensilla on them. Many researchers have studied the ultrastructure in adults flies to help increase the anatomical database on flies: Zhang et al. [26]; Zhang et al. [27]; Carriço et al. [2]; Pezzi et al. [15]; Carriço et al. [3].

An ultrastructure analysis of the morphological aspects of sensilla on the antennae and maxillary palps of Mesembrinella bellardiana; Mesembrinella bicolor (Fabricius, 1805) and Mesembrinella semihyalina Mello, 1967 have not been performed yet. The purpose of this study was to examine in details these sensorial organs on the aforementioned species to help increase the anatomical database for flies, arising implications for future phylogenetic analyses to be conducted with the group.

\section{Methods}

This research was carried out through the cooperation of Fundação Oswaldo Cruz (FIOCRUZ) and Instituto Samambaia de Ciências Ambientais e Ecoturismo (ISCAE), process number 176/2016.

Specimens of M. bellardiana; M. bicolor and M. semihyalina were obtained by sweeping with entomological net over a carcass of Oryctolagus sp. Collections were performed daily, during the month of October of 2016, in a Atlantic rainforest fragment at Instituto Samambaia de Ciências Ambientais e Ecoturismo (ISCA) -Petrópolis, Rio de Janeiro, Brazil $\left(22^{\circ} 46^{\prime} 90^{\prime \prime} \mathrm{S} ; 43^{\circ} 14^{\prime} 82^{\prime \prime} \mathrm{W}\right)$. The authorization for scientific research ICMBio/SisBio (Instituto Chico Mendes de Conservação da Biodiversidade/Sistema de Autorização e Informação em Biodiversidade) is 54,279.

Specimens were identified using the keys presented by Mello [12] and Kosmann et al. [8]. Adult morphological terminology used in this study followed McAlpine [11], Mello [12] and Kosmann et al. [8], the classification of sensilla followed by Setzu et al. [16]; Zhang et al. [26, 27].

The heads and palps were dissected from nine male and nine female of M. bellardiana and M. bicolor, and nine male of $M$. semihyalina under dissecting microscope. Then, these structures were processed for SEM examination by transferring to $2.5 \%$ of glutaraldehyde mixture in phosphatebuffered saline (PBS) for $24 \mathrm{~h}$. Afterwards, specimens were rinsed twice with PBS during 10-min- intervals and postfixed with $1 \%$ of osmium tetroxide at room temperature for 3 days. The flies were then rinsed twice with PBS and dehydrated in increasing graded series of alcohol (30, 50, 70, 80 and 90\%) for $12 \mathrm{~h}$ during each step. Thereafter, the flies were placed in absolute alcohol, followed by a treatment in acetone. On the next step, the specimens were subjected to critical point drying and they were later placed on metallic supports, coated with a thin golden layer $(20-30 \mathrm{~nm})$ and examined under JEOL 6390LV scanning electron microscope (SEM) (Akishima, Tokyo, Japan).

\section{Results}

All examined heads are equipped with a pair of antennae typical of cyclorrhaphan Diptera, which were frontally situated between the large compounds eyes (Fig. 1a-e). Antenna morphology of these species consisting of three segments: a short proximal scape $(\mathrm{Sc})$, a pedicel $(\mathrm{Pe})$ and a distal flagellum, the latter is composed of a seta called arista (Ar) located laterally and basal region of first flagellomere (Fn) enlarged (Fig. 1a-e).

The scape in Mesembrinella bellardiana is densely covered by microtrichia (Mc) in both genders. There is a group of seven chaetic sensilla (Ch I) of similar length, which was noticed arranged in a single row and curving over the base of the pedicel (Fig. 2a-b). The Ch I is longitudinally grooved and has a finely tapered, acute tip (Fig. 2a-b). The second antenna segment is called pedicel. The surface is covered by similar Mc to those found on the scape (Fig. 3a-b). The surface of the pedicel in both genders shows three types of chaetic sensilla (Ch I - Ch III). The first type (ChI) is represented by a group of 19-20 bristles on female and 13-14 on male situated along the outer edge region and similar to those found on the scape. The second type (Ch II) is represented by a group of five bristles in both genders, situated on the distal end region of the pedicel and the third type, also in both genders, is represented is represented by a singular bristle in the distal outer edge region (Fig. 3a-b).The distal flagellum is the longest antenna segment in both genders and numerous sensilla are found in this segment. Arising closed to the base of the first flagellomere on its dorsolateral surface is the plumose arista, which is composed of two segments on female, and three on male (Fig. 4a-b). The enlarged basal Fn is densely covered by microtrichia similar to those found on the scape and pedicel. Interspersed among the microtrichia, there are four types of sensilla on female Fn: trichoidea, two types of basiconic, and clavate; in the male Fn there are two types of sensilla: trichoidea and one of basiconic (Fig. $4 \mathrm{c}-\mathrm{d})$. Olfactory pits are also present on the Fn in both genders (Fig. 4c-d).

In the species Mesembrinella bicolor, the scape is also densely covered by microtrichia (Mc) in both genders. There is a group of eight chaetic sensilla (Ch I) in the 

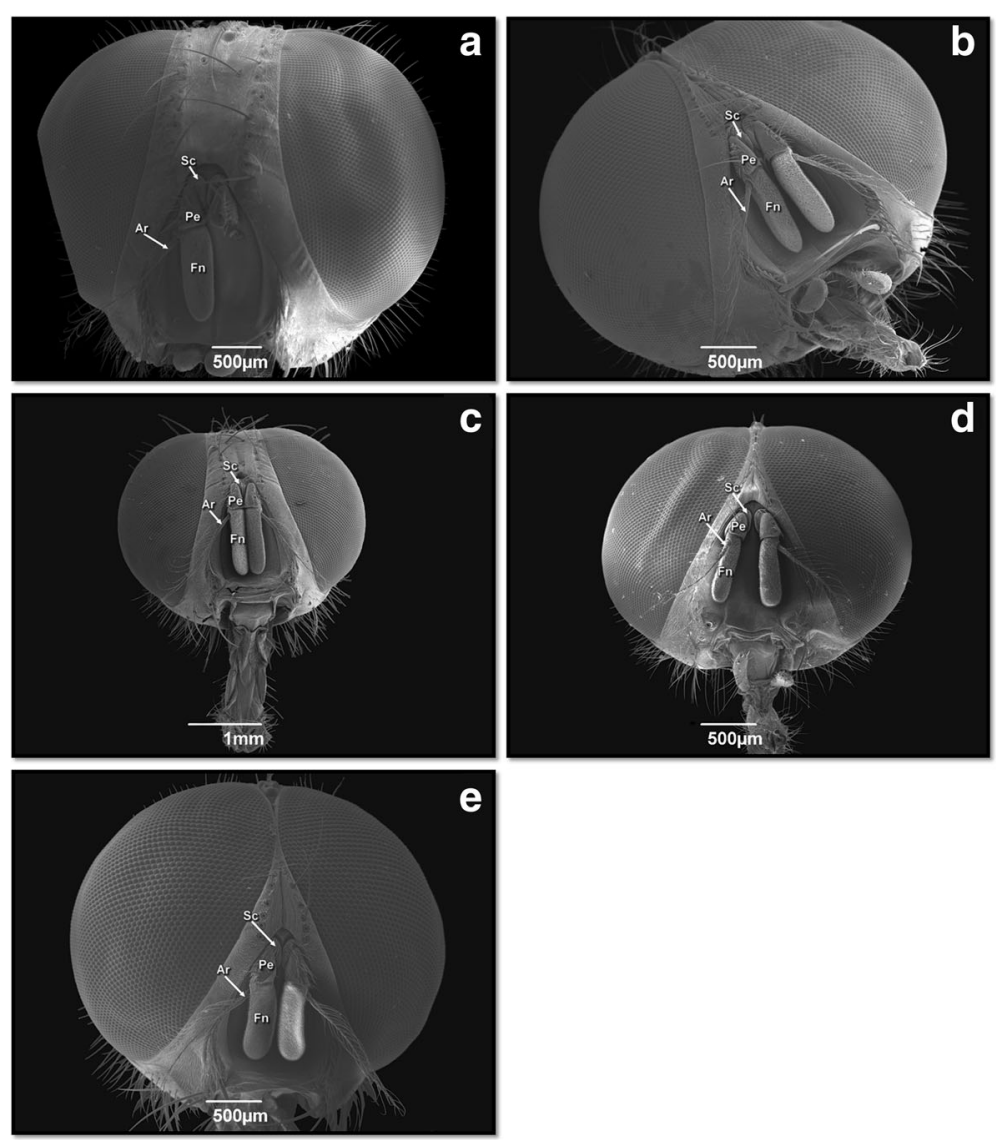

Fig. 1 Scanning electron micrographs showing the heads, in frontal view, of the different species analyzed. Mesembrinella bellardiana: a female

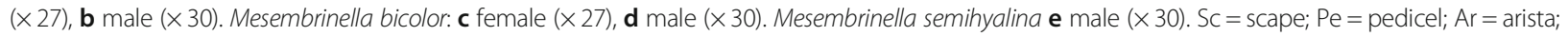
$\mathrm{Fn}=$ first flagellomere

female and seven in the male of similar length, which were arranged in a single row and curving over the base of the pedicel (Fig. 5a-b). The Ch I is longitudinally grooved and has a finely tapered, acute tip like, also observed in the $M$. bellardiana species (Fig. 5a-b). The pedicel surface is covered by Mc to those found on the scape (Fig. 6a-b). On pedicel surface in both genders, three types of chaetic sensilla (Ch I - Ch III) were observed. The first type (ChI) is represented by a group of eight bristles on female and five on male situated along the outer edge region and similar to those found on the scape. The second type (Ch II) is represented by a group of eight bristles on female and three on male situated on the distal region of the pedicel
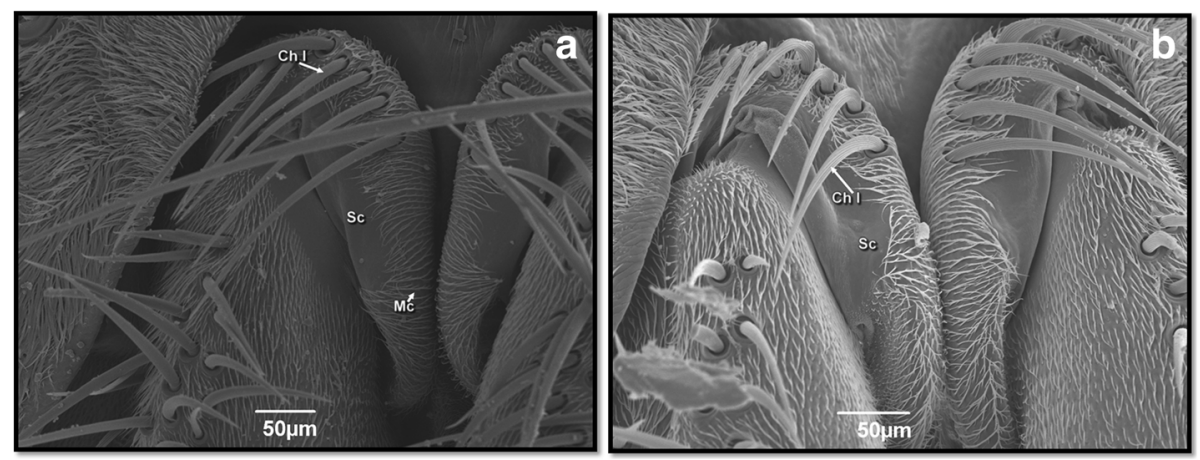

Fig. 2 Scanning electron micrographs showing the cuticular surface of scape in both genders of Mesembrinella bellardiana: a female ( $\times 270)$, b male ( $\times 330)$. Sc = scape; $\mathrm{Chl}=$ chaetic sensilla; $\mathrm{Mc}=$ microtrichia 

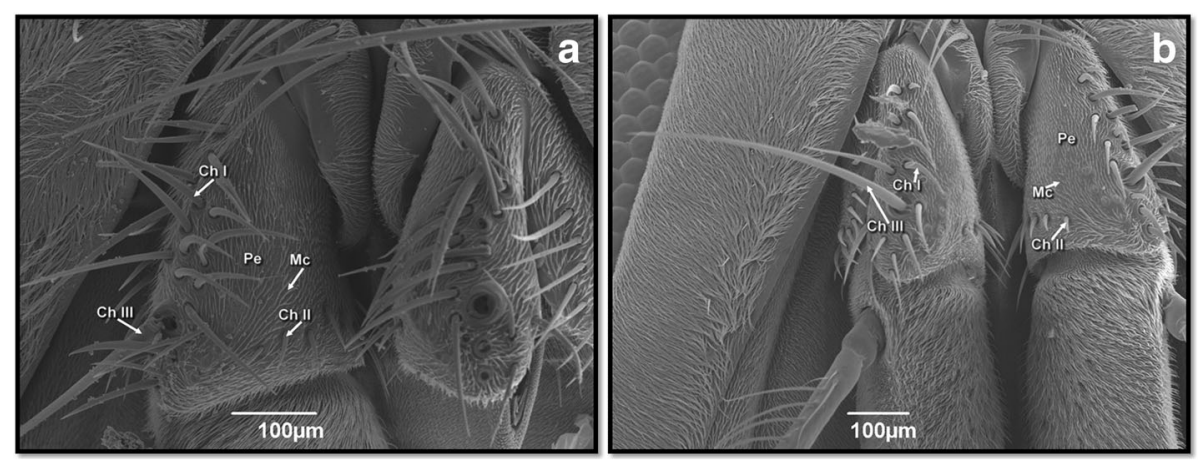

Fig. 3 Scanning electron micrographs showing the cuticular surface of pedicel in both genders of Mesembrinella bellardiana: a female ( $\times 190)$, b male $(\times 140)$. Pe = pedicel; Chl-ChIII = chaetic sensilla I, II and III; Mc = microtrichia

and the third type also in both genders is represented by a singular bristle in the distal outer edge region (Fig. 6a-b). Numerous sensilla are found in the flagellum in both genders. Arising close to the base of the first flagellomere on its dorsolateral surface is the plumose arista, which is composed of three segments on female with no sensilla and three on male. The first and the second aristomere are around, covered by short Mc, and the last one is longitudinally grooved and has a finely tapered, acute tip (Fig. 7a-b). The first flagellomere is densely covered by microtrichia, similar to those found on the scape and pedicel. Interspersed among the microtrichia there are two types of sensilla with a similar morphology in both genders: trichoidea and two types of basiconic (Fig. 7c-d). Olfactory pits are also present on the female Fn (Fig. 7c).

The scape of Mesembrinella semihyalina is densely covered by microtrichia (Mc) in male. There is a group of 11 chaetic sensilla (Ch I) on male (Fig. 8a). The Ch I on male is longitudinally grooved and has a finely tapered, acute tip (Fig. 8). The Pedicel surface is covered by similar Mc to those found on the scape (Fig. 9a), and on male, it shows two types of chaetic sensilla (Ch I and Ch III). The first type (ChI) is represented by a group of
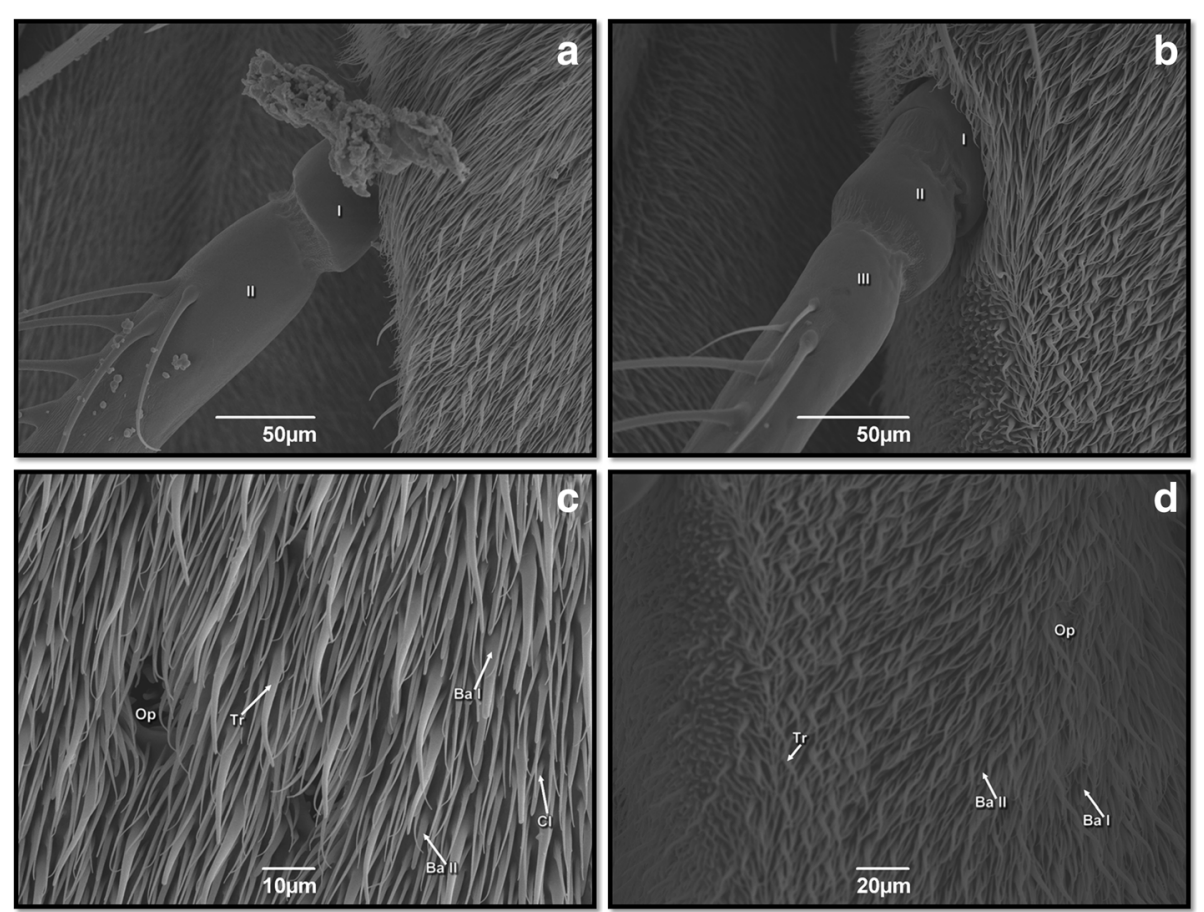

Fig. 4 Scanning electron micrographs showing the cuticular surface of flagellum in both genders of Mesembrinella bellardiana: a arista of female divided in two (I-II) segments (X 450), b arista of male divided in three (I-III) segments (X 500), c first flagellomere of female $(\times 1200)$; $\mathbf{d}$ first flagellomere of male $(\times 600)$. Fn = first flagellomere; $\mathrm{Mc}=$ microtrichia; $\mathrm{Tr}=$ trichoidea; $\mathrm{Ba}=$ basiconic; $\mathrm{Cl}=$ clavate; Op= Olfactory pits 

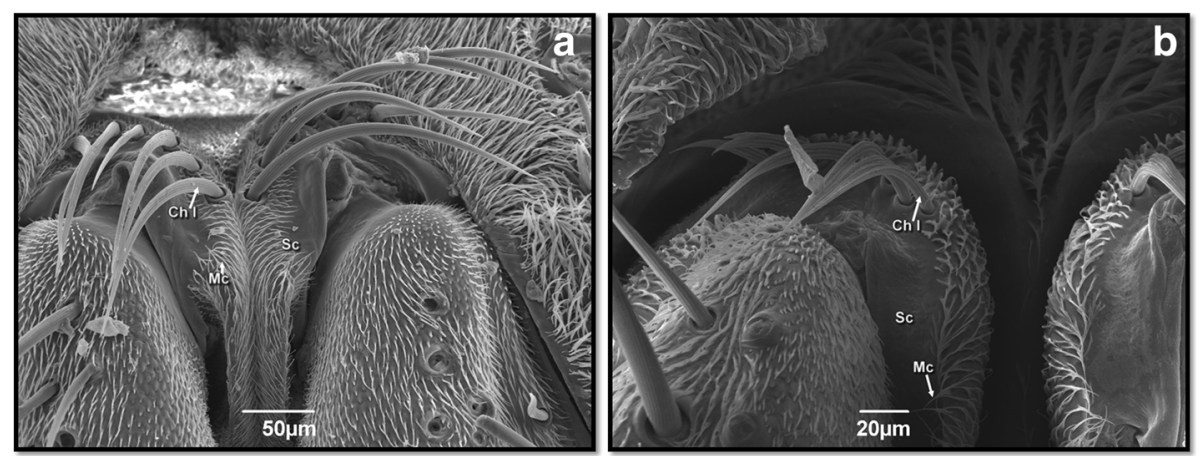

Fig. 5 Scanning electron micrographs showing the cuticular surface of scape in both genders of Mesembrinella bicolor: a female $(\times 330)$, $\mathbf{b}$ male $(\times 550)$. Sc = Scape; Ch I = chaetic sensilla; Mc = microtrichia

20 bristles on male situated along the pedicel and similar to those found on the scape. The third type is represented by a singular bristle in the distal outer edge region (Fig. 9a).The distal flagellum in male have numerous sensilla. The plumose arista is composed of two segments (Fig. 10a). The enlarged basal $\mathrm{Fn}$ is densely covered by microtrichia, similar to those found on the scape and pedicel. Interspersed among the microtrichia there are trichoidea-type sensilla (Fig. 10b).

The maxillary palps are inserted in the anterior region of the basiproboscis in all the species. Regarding the presence of sensilla, unlike the antennal characters, no significant differences were found among the analyzed species. The structure is covered with microtrichia of different length. Two different morphological types of sensilla are distributed on the palp surface: trichoidea-like $(\operatorname{Tr})$ and chaetic sensilla $(\mathrm{Ch})$, both morphologically similar to those observed on scape and pedicel (Fig. 11a-e).

\section{Discussion}

Ultrastructure studies using SEM of different anatomical structures of flies, such as antennae, mouth parts and genitalia, among others, have been performed for many taxonomic groups in the world. Stoffolano et al. [17] examined the abdominal tergites of Tabanus nigrovittatus Mcquart, 1847 in both genders and observed small pits on them, which may have a sensorial function, according to authors; Sukontason et al. [18] studied the antennal sensilla of flies of the families Calliphoridae, Muscidae and Sarcophagidae and they observed that the sensilla in all species are similar and suggested that each type had a function; Sukontason et al. [19] described the ultrastructure of the adhesive device in fly in families Calliphoridae, Muscidae and Sarcophagidae showing the smooth surface; Sukontason et al. [20] observed different types of sensilla in the antennal and palp of Ophyra chalcogaster (Wiedemann, 1824), trichoidea sensilla, chaetic sensilla and microtrichia, for instance; Chaiwong et al. [4] described the male genitalia of Sarcophaga dux and observed sensilla on the surface of postgonite, surstylus, epandrium and cerci; Setzu et al. [16] observed on the first flagellomere surface of Protophormia terraenovae Robineau-Desvoidy, 1830 five types of sensilla: microtrichia, trichchoidea, basiconic, coeloconic and ariculate; Zhang et al. [26] described four major types of surface sensilla: trichchoidea, basiconic, clavate and coeloconic on the first flagellomere of Fannia scalaris (Fabricius,
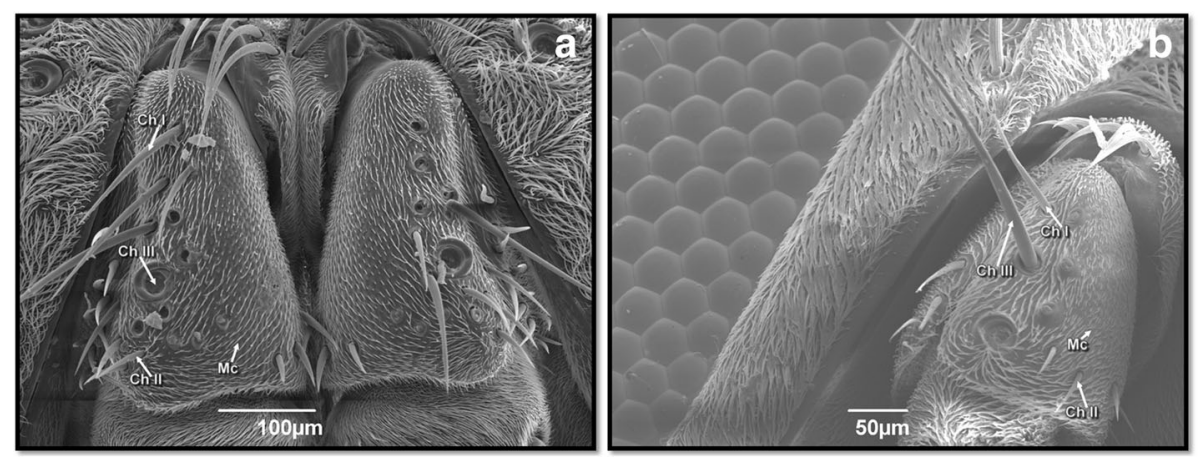

Fig. 6 Scanning electron micrographs showing the cuticular surface of pedicel in both genders of Mesembrinella bicolor: a female $(\times 220), \mathbf{b}$ male ( $\times 270)$. Pe = pedicel; ChI-ChIII = chaetic sensilla I, II and III; Mc = microtrichia 

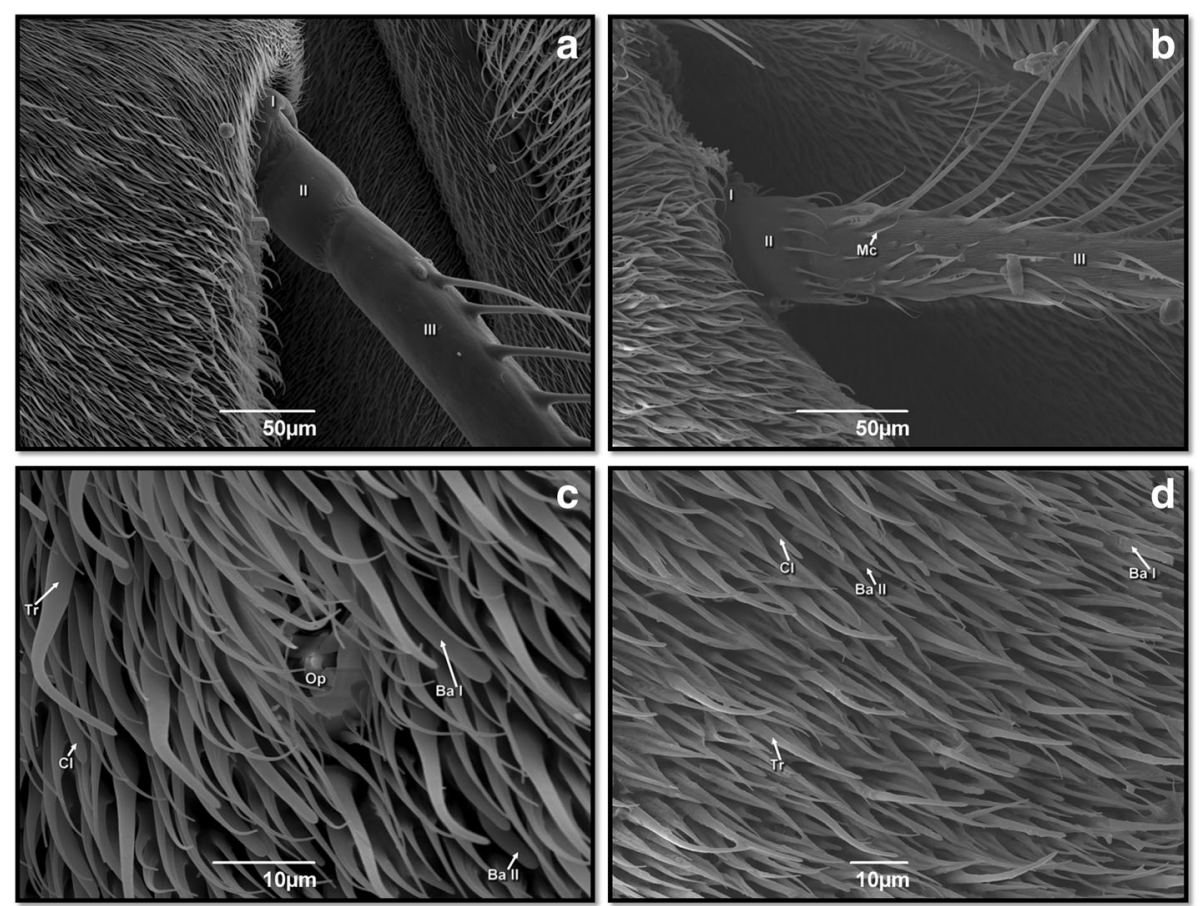

Fig. 7 Scanning electron micrographs showing the cuticular surface of flagellum in both gender of Mesembrinella bicolor: a arista of female divided in three (I-III) segments $(\times 430)$, b arista of male divided in three (IIII) segments $(\times 500)$, c first flagellomere of female $(\times 2,300)$, $\mathbf{d}$ first flagellomere of male $(\times 1,300)$. $\mathrm{Fn}=$ first flagellomere; $\mathrm{Mc}=$ microtrichia; $\mathrm{Tr}=$ trichoidea; $\mathrm{Ba}=$ basiconic; $\mathrm{Cl}=$ clavate; $\mathrm{Op}=\mathrm{Olfactory}$ pits

1794) and Fannia canicularis (Linnaeus, 1761); Carriço et al. [2] described some character of Muscidae species by using SEM, such as: ommatidia, ocellar triangle and antennae; Pezzi et al. [15] observed different types of sensilla on the antennae and maxillary palp in Sarcophaga tibialis Macquart, 1851.

The present study is the first describing the morphology of the different parts of the antennae and

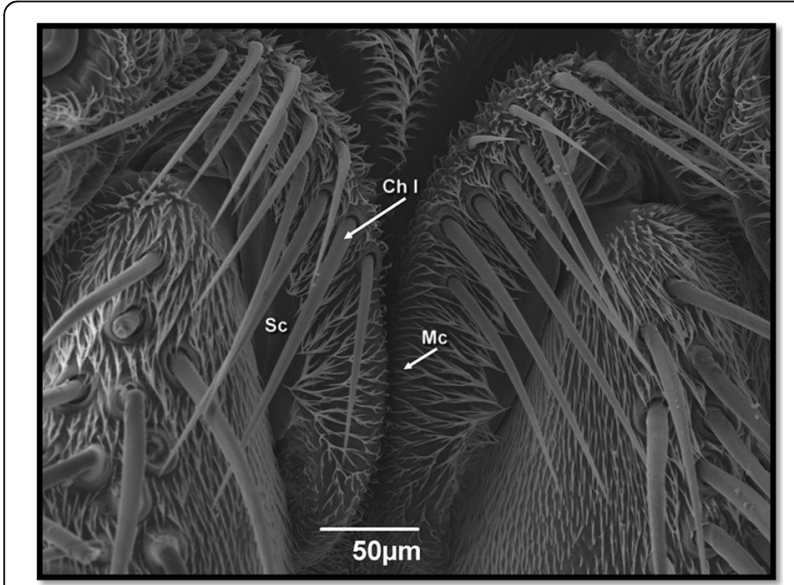

Fig. 8 Scanning electron micrographs showing the cuticular surface of scape of male of Mesembrinella semihyalina $(\times 350)$. Sc = Scape; $\mathrm{Chl}=$ chaetic sensilla; $\mathrm{Mc}=$ microtrichia maxillary palp by SEM of both sexes of $M$. bellardiana and $M$. bicolor and male of $M$. semihyalina. The morphology of the three antennal segments of the Mesembrinella species on this study is generally similar to those found in other calyptrate flies $[2,15,16,18$, $20,26,27]$. Sensory organs are distributed all over the body surface of the flies [2, 21]. Sensilla in the antennae and others parts of the insects have a role [18] to

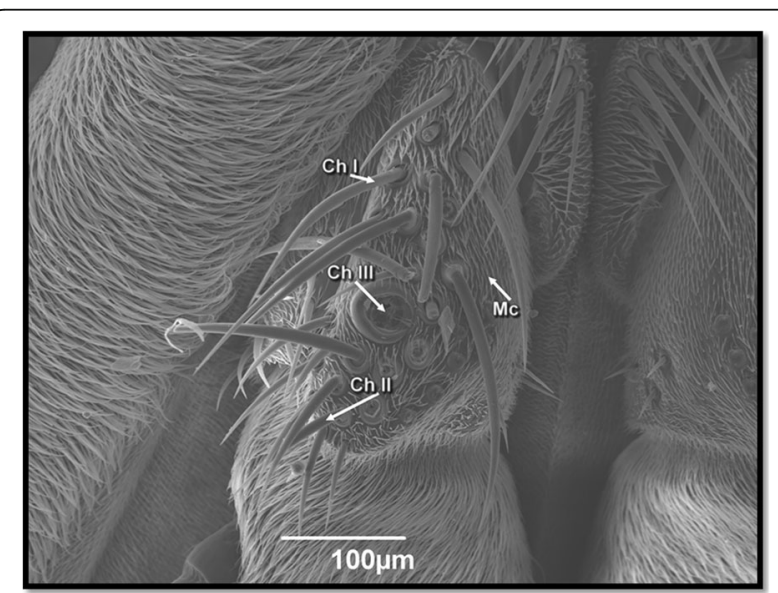

Fig. 9 Scanning electron micrographs showing the cuticular surface of pedicel of male of Mesembrinella semihyalina $(\times 220)$. Pe = Pedicel; ChI-III = chaetic sensilla I, II and III; MC = microtrichia 

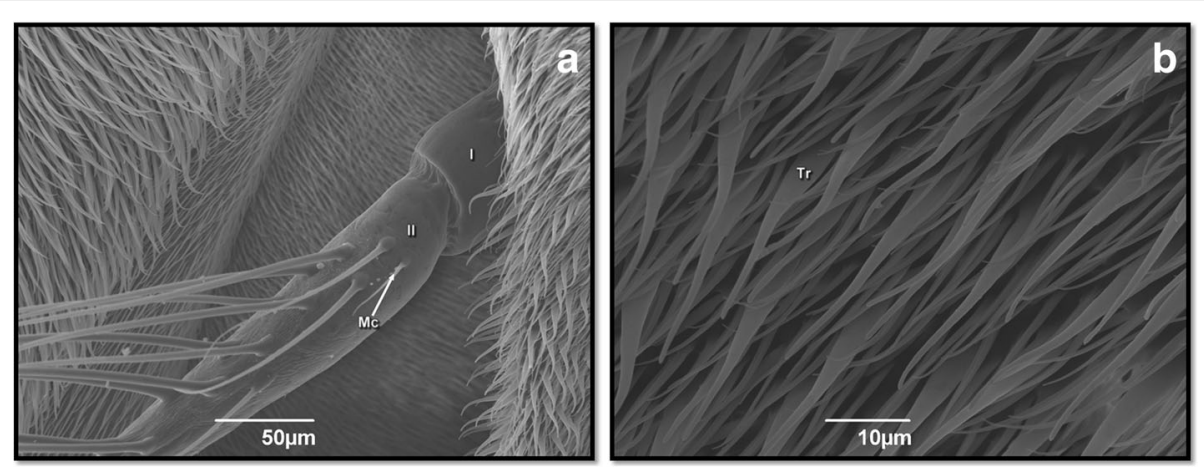

Fig. 10 Scanning electron micrographs showing the cuticular surface of flagellum of male of Mesembrinella semihyalina: $\mathbf{a}$ arista divided in two $(\mathbf{I}-\mathrm{II})$ segments $(\times 450)$; b first flagellomere $(\times 1,900)$. Fn = first flagellomere; $\mathrm{Mc}=$ microtrichia; $\mathrm{Tr}=$ trichoidea
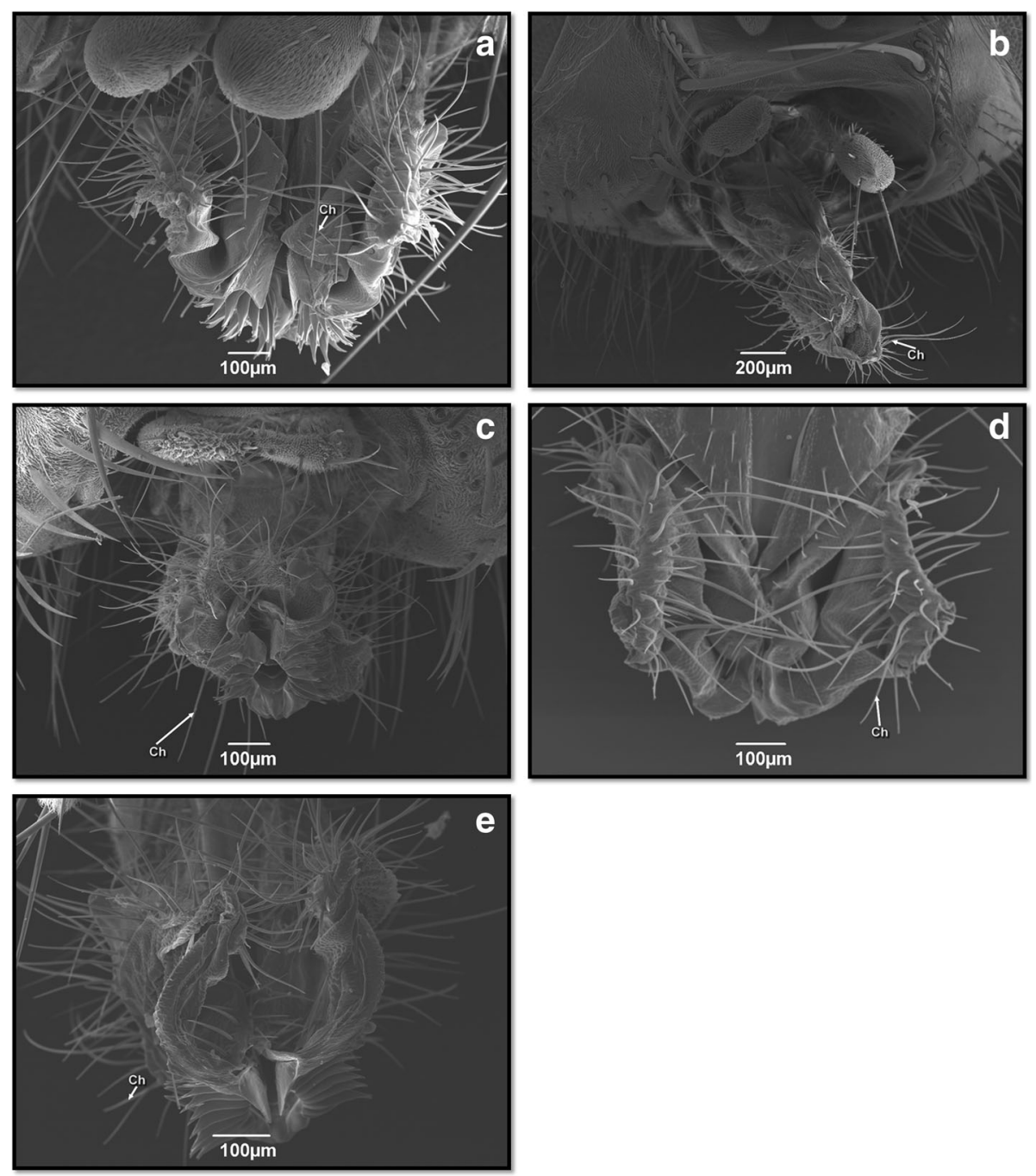

Fig. 11 Scanning electron micrographs showing the maxillary palps in frontal view, of the different species analyzed. Mesembrinella bellardiana: a female $(\times 110)$, b male $(\times 60)$. Mesembrinella bicolor: c female $(\times 110)$, d male $(\times 130)$. Mesembrinella semihyalina e male $(\times 150)$.

Ch $=$ chaetic sensilla 
detecting the opposite sex, food sources, orientation in space, and other aspects [26, 27].

In this investigation, the microtrichia morphology of the antennae is similar to those found in other calyptrate $[2,15,16,18,20,26,27]$ and are present on all antennal surface with a variable distribution. The chaetic sensilla were observed only in the scape (chI) and pedicel segments (ChI-ChIII). This distribution pattern was also found in Ophyra albuquerquei Lopes, 1985, Ophyra aenescens (Wiedemann, 1830) [2], O. chalcogaster [20] and S. tibialis [15].

The flagellum is an anatomical structure possessing olfactory organs that allows the detection of chemical cues from food sources $[7,16,26,27]$. This segment is the largest one of the antenna and its number of sensory sensilla can vary from species to species $[2,18]$. Three types of sensilla: trichoidea, basiconic and clavate were observed in the first flagellomere of M. bellardiana; and two types of sensilla: trichoidea and basiconic were noticed in M. bicolor and M. semihyalina. Those distribution were also described in other dipteran species, such as O. chalcogaster [20], Musca domestica Linnaeus, 1758 [18], F. scalaris and F. canicularis [27], Lispe neimongola Tian and Ma, 2000 [26] P. terraenovae [16], O. albuquerquei and $O$. aenescens [2]. In this study, olfactory pits were observed in both genders of $M$. bellardiana and female of M. bicolor species, and they are similar to those found in Sarcophaga dux Thomson, 1869 [18] and S. tibialis [15].

The maxillary palp of the Mesembrinella species in this study does not show sexual dimorphism and it was similar with other dipteran as O. chalcogaster [20], Fannia hirticeps (Stein, 1982) [22], L. neimongola [26] and $S$. tibialis [15].

\section{Conclusions}

In conclusion, this investigation provided new findings of some diagnostic structures of flies using SEM, since many of them are not possibly observed just by the use of light microscopy.

\section{Acknowledgements}

We thank Paulo Vander Ferreira Santana (professor from Prefeitura Municipal do Rio de Janeiro) for language editing. All authors acknowledge the Electron Microscopy Platform Rudolf Barth of Instituto Oswaldo Cruz (IOC/FIOCRUZ) for the use of the scanning electron microscope.

\section{Availability of data and materials}

Please, contact author for data requests.

\section{Authors' contributions}

RE contributed in writing the manuscript and editing the photos. CE took the photos under scanning electron microscope and contributed in writing the manuscript. DO contributed in writing the manuscript. ZE took the photos under scanning electron microscope and contributed in writing the manuscript. All authors read and approved the final manuscript.
Ethics approval and consent to participate

Not applicable

\section{Consent for publication}

Not applicable

Competing interests

The authors declare that they have no competing interests.

\section{Publisher's Note}

Springer Nature remains neutral with regard to jurisdictional claims in published maps and institutional affiliations.

\section{Author details}

IInstituto Oswaldo Cruz/Fundação Oswaldo Cruz (IOC/FIOCRUZ), Laboratório de Educação em Ambiente e Saúde, Avenida Brasil, 4365, Rio de Janeiro, RJ CEP 21040-900, Brazil. ²Universidade Estácio de Sá (UNESA), Rua Bingen, 50 Bingen, Petrópolis, RJ CEP 25660-004, Brazil. ${ }^{3}$ Instituto Brasileiro de Medicina de Reabilitação-IBMR/Laureate International Universities, Av. das Américas, 2603, Barra da Tijuca, Rio de Janeiro CEP 22631-002, Brazil.

Received: 9 March 2018 Accepted: 12 June 2018

Published online: 26 June 2018

\section{References}

1. Ameismeier F. Ultrastructure of the chemosensitive basiconic single-walled wall-pore sensilla on the antennae in adults and embryonic stages of Locusta migratoria L. (Insecta, Orthoptera). Cell Tissue Res. 1987;247:605-12. http://dx.doi.org/10.1007/BF00215755

2. Carriço C, Mendonça PM, Cortinhas LB, Mallet JRS, Queiroz MMC. Ultrastructural studies of some character of Diptera (Muscidae) of forensically importance. Acta Trop. 2015;142:96-102. http://dx.doi.org/10, 1016/j.actatropica.2014.11.005

3. Carriço C, Caetano RL, Barbán-Alvarez LDR, Pinto ZT. Morphology of flesh Fly Peckia (Peckia) chrysostoma (Diptera: Sarcophagidae) revealed by scanning Electron microscopy. Austin J Forensic Sci Criminol. 2017:4(2):1063.

4. Chaiwong T, Sukontason KL, Chaithong U, Olson JK, Kurahashi H, Sukontason K. Male genitalia of flesh fly Parasarcophaga (Liosarcophaga) dux (Diptera: Sarcophagidae) revealed by scanning electron miscroscopy. J Am Mosq Control Assoc. 2007;23(1):80-3. http://dx.doi.org/10.2987/8756971X(2007)23[80:MGOFFP]2.0.CO;2

5. Gadelha BQ, Ferraz ACP. Aguiar-Coelho VM. A importância dos mesembrinelíneos (Diptera: Calliphoridae) e seu potencial como indicadores de preservação ambiental. Oecologia Brasiliensis. 2009;13:661-5. http://dx. doi.org/10.4257/oeco.2009.1304.09

6. Guimarães JH. A systematic revision of the Mesembrinellidae, stat. nov. (Diptera, Cyclorrhapha). Arq Zool. 1977;29(1):109. http://dx.doi.org/10.11606/ issn.2176-7793.v29i1 p1-109

7. Greenberg B, Kunich JC. Entomology and the law: flies as forensic indicators. Cambridge: Cambridge University Press; 2002. p. 306.

8. Kosmann C, Mello RP, Harterreiten-Souza ES, Pujol-Luz JR. A list of current valid blow fly names (Diptera: Calliphoridae) in the Americas south of Mexico with key to the brasilian species. EntomoBras. 2013;6(1):74-85. http://dx.doi.org/10.12741/ebrasilis.v6i1.266

9. Lopes O, Barata EN, Mustaparta H, Araújo J. Fine structure of antennal sensilla basiconica and their detection of plant volatiles in the eucalyptus woodborer, Phoracantha semipunctata Fabricius (Coleoptera: Cerambycidae). Arthropod Struct Dev. 2002;31:1-13. http://dx.doi.org/10.1016/S14678039(02)00011-7

10. Marinho MAT, Wolff M, Ramos-Pastrana Y, Azeredo-Espin AML, Amorin DS The first phylogenetic study of Mesembrinellidae (Diptera: Oestroidea) based on molecular data: clades and congruence with morphological characters. Cladistics. 2016:1-19. http://dx.doi.org/10.1111/cla.12157

11. MCAlpine JF. Morphology and terminology - adults. In: MCAlpine JF, Peterson BV, Shewell GE, Teskey HJ, Vockeroth JR, Wood DM, editors. Manual of Neartic Diptera -1. Biosystematic Research Institute monograph. Agriculture Canada, Otawa, vol. 27; 1981. p. 9-63.

12. Mello RP. Chave para identificação das formas adultas das espécies da família Calliphoridae (Diptera, Brachycera, Cyclorrhapha) encontradas no Brasil. Entomologia y Vectores. 2003;10(2):255-68. 
13. Nascimento MA, Salomão TMF, Martins GF. Estudo comparativo das sensilas antenais de operárias de Melipona scutellaris Latreille (Hymenoptera: Apidae) de diferentes altitudes. Entomo Bras. 2013;6(1):64-7. http://dx.doi.org/10. 12741/ebrasilis.v6i1.252

14. Nuorteva P. Synanthropy of blowflies (Diptera: Calliphoridae) in Finland. Annales Entomologicae Fennicae. 1963;29:1-49.

15. Pezzi M, Whitmore D, Chicca M, Semeraro B, Brighi F, Leis M. Ultrastructural morphology of the antenna and maxillary palp of Sarcophaga tibialis (Diptera: Sarcophagidae). J Med Entomol. 2016;0(0):1-8. http://dx.doi.org/10. 1093/jme/tjw061

16. Setzu MD, Poddighe S, Angioy AM. Sensilla on the antennal funiculus of the blow fly, Protophormia terraenovae (Diptera: Calliphoridae). Micron. 2011;42: 471-7. http://dx.doi.org/10.1016/j.micron.2011.01.005

17. Stoffolano JG, Woodley NE, Borkent A, Yin LRS. Ultrastructural studies of the abdominal plaques of some Diptera. Ann. Entomol. Soc. Am. 1988;81(3): 503-10.

18. Sukontason K, Sukontason KL, Piangjaia S, Boonchua N, Chaiwonga T, Ngern-kluna R, Sripakdeea D, Vogtsbergerb RC, Olsonc JK. Antennal sensilla of some forensically importante flies in families Calliphoridae, Sacorphagidae and Muscidae. Micron. 2004;35:671-9. http://dx.doi.org/10. 1016/j.micron.2004.05.005

19. Sukontason KL, Bunchu N, Methanitikorn R, Chaiwong T, Kuntalue B, Sukontason K. Ultrastructure of adhesive devise in fly in families Calliphoridae, Muscidae and Sarcophagidae, and their implication as mechanical carries of pathogens. Parasitol Res. 2006;98:477-81. http://dx.doi. org/10.1007/s00436-005-0100-0

20. Sukontason K, Methanitikorn R, Chaiwong T, Kurahashi H, Vogtsberger RC, Sukontason KL. Sensilla of the antenna and palp of Hydrotaea chalcogaster (Diptera: Muscidae). Micron. 2007;38:218-23. http://dx.doi.org/10.1016/j. micron.2006.07.018

21. Sukontason K, Methanitikorn R, Kurahashi H, Vogtsberger RC, Sukontason KL. External morphology of Chrysomya pinguis (Walker) (Diptera:Calliphoridae) revealed by scanning electron microscopy. Micron. 2008;39:190-7. http://dx. doi.org/10.1016/j.micron.2007.01.004

22. Wang QK, Zhang M, Li K, Zhang D. Olfactory sensilla on antennae and maxillary palps of Fannia hirticeps (Stein, 1982) (Diptera: Fanniidae). Micron Res Tecnol. 2012;75:1313-20.

23. Wolff M. A new species of Mesembrinella (Diptera: Calliphoridae: Mesembrinellinae) from Colombia. Rev Colomb Entomol. 2013;39:120-4.

24. Wolff M, Ramos-Pastrana Y, Pujol-Luz JR. A new species of Giovanella (Diptera, Calliphoridae, Mesembrinellinae) from Colombia. Rev Bras de Entomol. 2013;57:129-32. http://dx.doi.org/10.1590/S008556262013005000013

25. Wolff M, Bonatto SR, Carvalho CJB. Review of Thompsoniella Guimarães with description of a new species from Colombia (Diptera, Calliphoridae, Mesembrinellinae). Rev Bras Entomol. 2014;58:319-25. http://dx.doi.org/10. 1590/50085-56262014005000002

26. Zhang D, Wang QK, Liu XH, Li K. Sensilla on antenna and maxillary palp of predaceous fly, Lispenei mongola Tian et Ma (Diptera: Muscidae). Micron. 2013a;49:33-9. http://dx.doi.org/10.1016/j.micron.2013.02.012

27. Zhang D, Wang QK, Yang YZ, Chen YO, Li K. Sensory organs of the antenna of two Fannia species (Diptera: Fanniidae). Parasitol Res. 2013b;112:2177-85. http://dx.doi.org/10.1007/s00436-013-3377-4

\section{Ready to submit your research? Choose BMC and benefit from:}

- fast, convenient online submission

- thorough peer review by experienced researchers in your field

- rapid publication on acceptance

- support for research data, including large and complex data types

- gold Open Access which fosters wider collaboration and increased citations

- maximum visibility for your research: over $100 \mathrm{M}$ website views per year

At BMC, research is always in progress.

Learn more biomedcentral.com/submissions 